\title{
Case-control study on vitamin D status in children and adolescents with eosinophilic esophagitis
}

\author{
Thaís Longo TEIXEIRA, Marcela Almeida LINDEN, Elizete Aparecida LOMAZI, \\ Margareth Galvão Lopes SARON, Adriana Lopes RICCETTO and Maria Ângela BELLOMO-BRANDÃO
}

Received: 3 April 2020

Accepted: 14 July 2020

\begin{abstract}
Background - Vitamin D is an essential fat-soluble steroid hormone and vitamin D deficiency is a global public health problem especially among children and adolescents. Factors such as the low intake of vitamin D-rich food sources, poor absorption and less exposure to the sun influence this outcome. Vitamin D has an anti-inflammatory effect in the body by promoting regulatory T cell differentiation as well as recovering T helper 17 cell response and secretion of anti-inflammatory cytokines. Eosinophilic esophagitis (EoE) is a chronic disease, histologically characterized by predominantly eosinophilic inflammation. The most common therapeutic approaches are allergen-eliminating diets, such as excluding cow's milk, egg, soy, wheat, peanuts and seafood, or more specific dietary restrictions. Objective - To verify the serum levels of vitamin D in children and adolescents with eosinophilic esophagitis on a restricted food diet and to analyze their association with nutritional status, consumption of different food sources, exposure to the sun and skin color. Methods - Case-control study conducted in the city of Campinas-SP, Brazil, in which included patients were aged 2 to 18 years old, and those diagnosed with eosinophilic esophagitis was referred to as the case group $(\mathrm{n}=15)$, meanwhile a control group ( $\mathrm{n}=17)$ was also formed. Epidemiological data, nutritional status, data on vitamin D intake (24-hour recall - performed only by EoE patients - and self-reported intake of vitamin D food sources: milk and dairy products, canned tuna and sardines, Bull's liver, chicken eggs - applied in both groups), and daily time of sun exposure ( $\geq 30 \mathrm{~min}$ or $\leq 30 \mathrm{~min}$ ) were recorded. The samples were collected for serum levels of 25 -hydroxy-vitamin $\mathrm{D}$, where sufficiency levels $>30 \mathrm{ng} / \mathrm{mL}$ were considered, insufficiency 21 to $30 \mathrm{ng} / \mathrm{mL}$, deficiency $<20 \mathrm{ng} / \mathrm{mL}$. Results - There was a higher frequency of vitamin D insufficiency/ deficiency in the Eosinophilic Esophagitis group $(P=0.035)$, even with longer sun exposure $(P=0.035)$. Skin color was not associated with lower levels of vitamin D in both groups studied. No difference was found in nutritional status between the groups. Conclusion - The present study demonstrated a higher frequency of inadequate/ deficient levels of vitamin D in children and adolescents with EoE on a restricted diet. When necessary, serum levels should be investigated and correct exposure to the sun should be encouraged, with special attention to the recommended guidelines, time spent in the sun and the appropriate clothing for correct absorption. Since exposure for more than 30 minutes in the sun does not appear to have provided a protective effect in the EoE group, even in a region with high levels of solar radiation. There was a significant difference only in the consumption of cow's milk between the case and control groups, demonstrating the low adherence to the restriction diet by the case group. No association was found between serum 25 hydroxyvitamin D levels and nutritional status. Moreover, no association regarding the adequate or inadequate status of 25 hydroxyvitamin D and the consumption vitamin D-rich foods was identified. Multicentered studies with a larger number of cases should be performed to assess serum 25 hydroxyvitamin D levels and associated factors in pediatric patients with EoE.
\end{abstract}

HEADINGS - Vitamin D deficiency. Vitamin D. Eosinophilic esophagitis. Child.

\section{INTRODUCTION}

Vitamin D is an essential fat-soluble steroid hormone for the human body. It is obtained from the reaction between type B ultraviolet radiation and animal-based cholesterol or vegetable-based ergosterol. The first step of vitamin D biosynthesis involves an action of the sun's ultraviolet radiation on 7-dehydrocholesterol in skin. With sun exposure, 7-dehydrocholesterol is converted to pre-vitamin D3 which is then isomerized into the vitamin D3. Vitamin D3 is hydroxylated in the liver by 25-hydroxylase, making 25-hydroxyvitamin D3 (25(OH)D) the major circulating metabolite. This isoform then goes to the kidneys where, by the action of 1-alpha hydroxylase, it becomes the biologically active form, 1,25-dihydroxyvitamin D3 $\left(1,25(\mathrm{OH})_{2} \text { D3 }\right)^{(1)}$.
Vitamin D deficiency is a global public health problem, with a high prevalence among children and adolescents. Factors, such as low intake of vitamin D-rich food sources, poor absorption and less exposure to the sun influence this outcome. Deficiency is associated with high levels of circulating inflammatory mediators and, therefore, seems to participate in the pathophysiology of different diseases, such as, obesity, high blood pressure, diabetes mellitus, among others ${ }^{(2)}$.

According to Ferreira et al. (2017) ${ }^{(3)}$, pregnant women, the elderly, patients with bone diseases (osteomalacia, rickets, osteoporosis), as well as endocrine diseases (secondary hyperparathyroidism), inflammatory and autoimmune diseases, chronic kidney disease and morbid obesity are the main patients at risk for vitamin $\mathrm{D}$ deficiency. Children with cow's milk protein allergies also have lower levels of this vitamin than the healthy population ${ }^{(4-6)}$.

Declared conflict of interest of all authors: none

Disclosure of funding: this study received funding from the Fundo de Apoio ao Ensino, à Pesquisa e Extensão (FAEPEX - Teaching Research and Extension Support Fund); Coordenação de Aperfeiçoamento de Pessoal de Nivel Superior (CAPES - Coordination for the Improvement of Higher Education Personnel).

Universidade Estadual de Campinas, Faculdade de Ciências Médicas, Departamento de Saúde da Criança e do Adolescente, Campinas, SP, Brasil.

Corresponding author: Thaís Longo Teixeira. E-mail: thaislongodemorais@cloud.com 
The immunomodulatory role of vitamin D has gained prominence in the literature. This function of vitamin $\mathrm{D}$ was discovered because immune cells, such as dendritic cells, macrophages, B and $\mathrm{T}$ cells, express vitamin $\mathrm{D}$ receptor $(\mathrm{VDR})^{(2)}$. Moreover, vitamin $\mathrm{D}$ decreases the proliferation of $\mathrm{T}$ helper cells proliferation, reduces production of interferon gamma (IFN- $\gamma$ ), IL2 and IL-5, and increases the production of IL-4(7). In fact, vitamin D affects the polarization of Th cells by inhibiting Th1 cell activity (production of IFN-gamma) and increasing the development of Th2 cells (production of IL-4, IL-5 and IL-10) ${ }^{(8,9)}$. In addition to the anti-inflammatory role of vitamin $\mathrm{D}$, severe and prolonged deficiency can lead to delayed growth and development of children and adolescents ${ }^{(10)}$.

Eosinophilic esophagitis (EoE) is a chronic disease, characterized histologically by predominantly eosinophilic inflammation ${ }^{(11)}$, and fibrosis can also be observed ${ }^{(9)}$. It has a prevalence of 37 per 100,000 pediatric patients ${ }^{(12)}$. International protocols recommend initializing of the use Proton Pump Inhibitors (PPIs) for 8 to 12 weeks, and then the endoscopy should be repeated. If biopsies show a decrease in eosinophils to less than 15 eosinophils/high magnification field (eos/HMF), the patient is maintained on PPI's alone and the recommended dose is reduced to once daily. If the patient does not respond to PPIs without decreasing eosinophil numbers (below 15 eos/HMF), consideration should be given to the indication of other therapeutic options, such allergen elimination diets (cow's milk, egg, soy, wheat, peanut and seafood) or specific food restrictions, which are most often of cow's milk and dairy products ${ }^{(13,14)}$.

There is only one study that evaluated $25(\mathrm{OH}) \mathrm{D}$ levels in pediatric and adult patients with EoE, which did not emphasize the period of growth and development ${ }^{(14)}$. In addition, no studies were found that verified the levels of $25(\mathrm{OH}) \mathrm{D}$ in children and adolescents with EoE in regions of high incidence of sun exposure. This may be associated with the fact that there are no routine diagnostic or replacement recommendations for vitamin D designated in eosinophilic esophagitis.

Since vitamin D plays an important role in the growth and development of children and adolescents, suboptimal levels might interfere with the nutritional status of this population. In addition, correct exposure to the sun and vitamin D consumption within the daily recommendations are very important for maintaining sufficient $25(\mathrm{OH}) \mathrm{D}$ levels. Therefore, the purpose of this retrospective case-control study was to verify whether there are differences between serum of $25(\mathrm{OH}) \mathrm{D}$ levels in children and adolescents with eosinophilic esophagitis on a restricted diet and children and adolescents without associated pathologies, and, later, to analyze the association of serum levels with status nutrition, food sources and sun exposure.

The hypothesis of this study is that insufficient or deficient $25(\mathrm{OH}) \mathrm{D}$ levels may be associated with the nutritional status of EoE patients, and that low exposure to the sun and low consumption of vitamin D-rich foods may favor low levels $25(\mathrm{OH}) \mathrm{D}$.

\section{METHODS}

This was an observational case-control study, with convenience sampling, carried out in the city of Campinas-SP, Brazil, in which included patients were aged 2 to 18 years old. Those diagnosed with eosinophilic esophagitis were included in the case group, meanwhile a control group of patients treated with chronic functional constipation and without associated comorbidities was also formed.
Participants were invited to participate in the study during routine visits at the Pediatric Gastroenterology Outpatient Clinic of the School of Medical Sciences at Universidade Estadual de Campinas (UNICAMP), between 2017 and 2018.

The patients and the parents of patients younger than 18 years were verbally informed about the study's objectives and signed the Informed Consent Form (ICF). The research project was registered with the National Research Ethics Commission (Conep / Plataforma Brasil) and submitted to the Research Ethics Committee of the School of Medical Sciences of Unicamp - SP, and was approved under the Certificate of Ethical Approval: 74967017.9.0000.5404 and the opinion number of the Ethics Committee: 2.879.988.

The inclusion criteria for patients with EoE were: 1) those who underwent at least one upper gastrointestinal endoscopy with biopsies of the esophagus, in which the infiltration of eosinophilic tissue was of 15 or more eosinophils by large field magnification; 2 ) those on a diet restricted of at least one food group (cow's milk, egg, soy, wheat, peanuts and seafood) - the food restriction can be of the six food groups or specific foods; 3 ) those that were already in long-term follow-up; and 4) those that already verified allergies to only one or more specific foods. Moreover, the patients were not taking vitamin D supplementation and agreed to participate in the study. Patients treated exclusively with PPIs, without dietary restrictions, diagnosed with intestinal, hepatic or renal comorbidities that could affect vitamin D metabolism or chose not to participate in the study were excluded from the study. The control group consisted of patients diagnosed with functional intestinal constipation, followed up at the pediatrics outpatient clinic of Unicamp clinical hospital.

Demographical and epidemiological data (name, chart number, date of birth, current age, sex, skin color), data on vitamin D intake (food recall of the last 24 hours and ingestion of vitamin D food sources: milk and dairy products, canned tuna and sardines, bull's liver, chicken eggs) and daily sun exposure times were collected.

The nutritional status of the participants was evaluated by measuring their weight in kilograms and grams $(\mathrm{kg})$ and height in meters $(\mathrm{m})$ before the start of the consultation, by a trained nurse, and the body mass index (BMI) was calculated by dividing their weight $(\mathrm{kg})$ by their squared height $\left(\mathrm{m}^{2}\right)$. Weight was measured on a Welmy ${ }^{\circledR}$ digital scale with a capacity of $200 \mathrm{~kg}(0.1 \mathrm{~kg}$ accuracy $)$ and height was measured by a compact tape-type stadiometer attached to the Sanny ${ }^{\circledR}$ wall, with a measuring range from 0 to 210 centimeters ( 2.1 meters). The BMI classification by age was given according to the cut-off points recommended by the World Health Organization for 0 to 5 years and 5 to 19 years $(2007)^{(15)}$. After the nutritional status evaluation, participants of the study were classified as normal/high BMI (whether eutrophic, overweight or obese) or low BMI (whether underweight or very low), and the statistical analysis was adjusted for BMI and age.

The cutoff point of 30 minutes of sun exposure to trigger adequate vitamin D production was chosen based on the literature ${ }^{(16)}$, and the patients were grouped into: exposure up to 30 minutes per day or above 30 minutes per day.

Food consumption was assessed by a qualitative food frequency questionnaire for vitamin D food sources (milk, dairy products, canned sardines, canned tuna, bull's liver, chicken eggs), applied directly to the users and their caregivers. Patients who reported consumption one to thre times a week, four to seven times a week or at least once a month, were grouped into the "Yes" group; i.e. they consumed these foods regularly. Those who reported rarely or 
never consuming were grouped into the "No" group; i.e. they did not consume the vitamin D food source regularly.

For the patients with EoE, in order to verify the daily intake of vitamin D, a 24-hour Recall was applied. Then the amount of consumption was calculated by AVANUTRI ${ }^{\circledR(17)}$ software and compared with the values recommended by Dietary Reference Intakes ${ }^{(18)}$

Regarding vitamin D, levels and degrees of sufficiency were analyzed, categorized as insufficient, deficient or sufficient. Statistical analysis considered 25(OH)D levels according to Endocrine Society Clinical Practice Guideline (2011) ${ }^{(19)}$, where levels below $20 \mathrm{ng} / \mathrm{mL}$ are considered deficient, levels between $21-29 \mathrm{ng} / \mathrm{mL}$ as insufficient and levels equal to or greater than greater than 30 $\mathrm{ng} / \mathrm{mL}$ as sufficient. Participants with insufficiency and deficiency were considered as a single group and participants with sufficiency in another. Patients with insufficient and deficient 25(OH)D levels were treated according to the recommendations. Those who were insufficient were instructed to expose themselves to the sun at the correct time, for a sufficient amount of time (30 minutes between 10 a.m. and 3 p.m., depending on skin color) and with appropriate clothes for correct absorption of UVB rays and to consume Bull's liver and mushrooms, when possible. And those who were deficient also received these recommendations, along with a recommended vitamin D supplementation (800 IU per day, according to the provision of supplementation by the public health system) for 3 months and returned for a new assessment. $25(\mathrm{OH}) \mathrm{D}$ levels were measured by chemiluminescence (Diasorin ${ }^{\circledR}$ commercial kit) $)^{(3,19)}$.

Statistical analyses were performed using OpenEpi software, Version 3.01 ${ }^{(20)}$ and Statistical Package for Social Sciences (SPSS) version 15.0 for Windows ${ }^{(21)}$. The unilateral Fisher exact test was used to evaluate the association between two qualitative variables. To compare the age distributions between the groups the MannWhitney test was used as the age had no normal distribution. To compare the vitamin D averages, Student's $t$-test was used after verifying the normal distribution in the measured values. Since the two groups were small, the bootstrap technique with 5,000 samples was used to guarantee greater precision in the test result. The $95 \%$ confidence interval of the difference between the means of the two groups was determined. The level of significance was $5 \%(\alpha=0.05)$. The sample of the present study was a convenience sample, as it is a rare pathology. The patients were approached as they go to consultations and when they have a confirmed diagnosis.

The data sets used and/or analyzed during the current study can be made available by the corresponding author upon reasonable request, yet since this was a clinical study, the anonymity of the participants will be preserved.

The preparation of this study was performed following the recommendations of the SPIRIT 2013 checklist for the definition of standard protocol items for clinical trials ${ }^{(22)}$.

\section{RESULTS}

Thirty-two patients were selected, where fifteen participants were from the EoE group and 17 from the control group. The median age of the EoE group was 9 years (minimum: 3 years, maximum: 18 years, standard deviation: 5.45 years), for the children and adolescents of the control group it was 11 years (minimum: 3 years, maximum: 17 years, standard deviation: 4.94 years). Male patients were more frequent in the series, $87 \%$ in the EoE group and $70 \%$ in the control group.
Regarding the nutritional status of the EoE group, two patients were underweight for their age, 12 were eutrophic and only one was obese. In the control group, ten patients were eutrophic for their age, four were overweight, two were obese, and one subject was underweight for their age.

The reported skin color of the individuals of both groups was either white or brown, $40 \%$ in the case group and $59 \%$ in the control group were self-described whites $(P=0.239)$; there were no patients who claimed to be black. There was a similar distribution concerning the prevalence of daily sun exposure: $73 \%$ of the EoE group and $82 \%$ of the control group $(P=0.424)$. However, the time of sun exposure differed between groups; $73 \%$ with EoE reported remaining in the sun for more than 30 minutes daily, and only $35 \%$ in the control group reported remaining for the same amount of time $(P=0.035)$. Sun exposure occurred during walks to school or at school break times, using pants and short-sleeved shirts. TABLE 1

TABLE 1. Clinical and sociodemographic characteristics and vitamin $\mathrm{D}$ status of children and adolescents with eosinophilic esophagitis and the control group attended at the Clinical Hospital of UNICAMP - SP (2017-2018).

\begin{tabular}{|c|c|c|c|c|c|}
\hline Variables & $\begin{array}{l}\text { Eosinophilic } \\
\text { esophagitis } \\
\text { group n (15) }\end{array}$ & $\%$ & $\begin{array}{l}\text { Group } \\
\text { control } \\
\mathrm{n}(17)\end{array}$ & $\%$ & $P$-value* \\
\hline \multicolumn{6}{|l|}{ Sex } \\
\hline Male & 13 & 87 & 12 & 71 & \multirow{2}{*}{0.254} \\
\hline Female & 2 & 13 & 5 & 29 & \\
\hline \multicolumn{6}{|l|}{ Age } \\
\hline $\begin{array}{l}\text { Child (up to } 12 \\
\text { years old) }\end{array}$ & 6 & 40 & 8 & 47 & \multirow{2}{*}{0.482} \\
\hline $\begin{array}{l}\text { Adolescent (12 to } \\
18 \text { years old) }\end{array}$ & 9 & 60 & 9 & 53 & \\
\hline \multicolumn{6}{|c|}{ Nutritional status (BMI/Age) } \\
\hline Low BMI & 2 & 13 & 1 & 6 & \multirow{2}{*}{0.451} \\
\hline Normal/high BMI & 13 & 87 & 16 & 94 & \\
\hline \multicolumn{6}{|l|}{ Sun exposure } \\
\hline Yes & 11 & 73 & 14 & 82 & \multirow{2}{*}{0.424} \\
\hline No & 4 & 27 & 3 & 18 & \\
\hline \multicolumn{6}{|l|}{ Sun exposure time } \\
\hline Up to 30 minutes & 4 & 27 & 11 & 65 & \multirow[b]{2}{*}{0.035} \\
\hline $\begin{array}{l}\text { More than } 30 \\
\text { minutes }\end{array}$ & 11 & 73 & 6 & 35 & \\
\hline \multicolumn{6}{|c|}{ Self-described skin color } \\
\hline White & 6 & 20 & 10 & 59 & \multirow{2}{*}{0.239} \\
\hline Brown & 9 & 80 & 7 & 41 & \\
\hline \multicolumn{6}{|l|}{ Levels of vitamin D } \\
\hline $\begin{array}{l}\text { Sufficient (equal } \\
\text { or greater than } \\
30 \mathrm{ng} / \mathrm{mL} \text { ) }\end{array}$ & 4 & 27 & 11 & 65 & \multirow{2}{*}{0.035} \\
\hline $\begin{array}{l}\text { Insufficient/ } \\
\text { deficient (below } \\
30 \mathrm{ng} / \mathrm{mL} \text { ) }\end{array}$ & 11 & 73 & 6 & 35 & \\
\hline
\end{tabular}

\footnotetext{
*Fisher's exact test. BMI: body mass index
} 
presents the results of the clinical and sociodemographic characteristics and vitamin D status of the children and adolescents of the EoE group and the control group.

The mean 25(OH)D levels among children and adolescents in the EoE group was $27.2 \pm 8.50 \mathrm{ng} / \mathrm{mL}$, and in the control group it was $32.47 \pm 8.87 \mathrm{ng} / \mathrm{mL}(P=0.096)$. After subdividing the groups in relation to serum $25(\mathrm{OH}) \mathrm{D}$ levels in sufficient or insufficient/ deficient, it was observed that there was a higher frequency of insufficient/deficient levels in patients in the EoE group, compared with the control group $(P=0.035)$. In the EoE group, four were vitamin $\mathrm{D}$ deficient $(<20 \mathrm{ng} / \mathrm{mL})$, seven had levels ranging from 20 to $30 \mathrm{ng} / \mathrm{mL}$ and only four subjects were at recommended levels (>30 mg/mL).

In relation to the consumption of vitamin D food sources, $82 \%$ patients in the control group consumed milk frequently, and only $40 \%$ of the patients in the EoE group reported any consumption $(P=0.016)$. Concerning dairy products, chicken eggs, canned sardines, canned tuna and bull's liver, a frequency of consumption was not observed in both groups (TABLE 2). In the case group, 7\% patients reported consuming milk and dairy products, $13 \%$ reported consuming eggs and 20\% reported eating bull's liver at least once a month. The daily intake of vitamin $\mathrm{D}$ in children and adolescents of the EoE group was inadequate for $93 \%$ patients.

TABLE 2. Frequency of vitamin D-rich food consumption of patients with eosinophilic esophagitis and of the control group attended at the Clinical Hospital of UNICAMP - SP (2017-2018).

\begin{tabular}{|c|c|c|c|c|c|}
\hline $\begin{array}{l}\text { Variables } \\
\text { Do you consume } \\
\text { frequently? }\end{array}$ & $\begin{array}{l}\text { Eosinophilic } \\
\text { esophagitis } \\
\text { group } \\
\text { n (15) }\end{array}$ & $\%$ & $\begin{array}{c}\text { Group } \\
\text { control } \\
\mathrm{n}(17)\end{array}$ & $\%$ & $P$-value \\
\hline \multicolumn{6}{|l|}{ Cow milk } \\
\hline Yes & 6 & 40 & 14 & 82 & \multirow{2}{*}{0.016} \\
\hline No & 9 & 60 & 3 & 18 & \\
\hline \multicolumn{6}{|l|}{ Dairy products } \\
\hline Yes & 10 & 67 & 13 & 77 & \multirow{2}{*}{0.411} \\
\hline No & 5 & 33 & 4 & 23 & \\
\hline \multicolumn{6}{|l|}{ Eggs } \\
\hline Yes & 9 & 60 & 14 & 82 & \multirow{2}{*}{0.156} \\
\hline No & 6 & 40 & 3 & 18 & \\
\hline \multicolumn{6}{|l|}{ Canned sardines } \\
\hline Yes & 0 & 0 & 3 & 18 & \multirow{2}{*}{0.137} \\
\hline No & 15 & 100 & 14 & 82 & \\
\hline \multicolumn{6}{|l|}{ Canned tuna } \\
\hline Yes & 0 & 0 & 0 & 0 & \multirow{2}{*}{1.000} \\
\hline No & 15 & 100 & 17 & 100 & \\
\hline \multicolumn{6}{|l|}{ Bull's liver } \\
\hline Yes & 2 & 13 & 3 & 18 & \multirow{2}{*}{0.562} \\
\hline No & 13 & 87 & 14 & 82 & \\
\hline
\end{tabular}

*Fisher's exact test. BMI: body mass index.

\section{DISCUSSION}

The objective of this study was to verify whether there are differences between serum vitamin $\mathrm{D}$ levels in children and adolescents with eosinophilic esophagitis on a restricted diet and children and adolescents without associated pathologies. In addition, the objective was also to verify if there would be an association between serum $25(\mathrm{OH})$ D levels with nutritional status, dietary sources and exposure to the sun. It was found that there was a higher frequency of vitamin D insufficiency/deficiency in the EoE group; even with greater exposure to the $\operatorname{sun}^{(5)}$. It is alarming that, even in a country with a high incidence of sunlight, there is a risk of vitamin D insufficiency/ deficiency. Skin color was not associated with lower levels of vitamin $\mathrm{D}$ in the two groups studied and no difference was found between the nutritional status of the groups. The consumption of vitamin D food sources only varied significantly for cow's milk between the groups. It is then warned of low adherence to treatment, indicating the need to emphasize, to the patients and those responsible, the importance of adhering to the treatment, for a good prognosis of the disease ${ }^{(24)}$.

Pediatric patients with EoE had insufficient serum levels of vitamin $\mathrm{D}$ when compared to those in the control group. However, there was no statistical difference between the averages of serum vitamin D. In relation to vitamin D sufficiency levels, the control group proved to be more insufficient/deficient than the case group. Mehta et al. (2018), carried out a study where they analyzed children with Gastroesophageal Reflux Disease (GERD) and EoE, with the objective of measuring the frequency of undiagnosed food dysfunction and nutritional deficiencies caused by food restriction in children with EoE and comparing them with those who had GERD. They noted that children with EoE and GERD had average normal levels of vitamin $\mathrm{D}(30.3 \pm 8.8)$ and no differences were found in the average values of vitamin $D$ in individuals with EoE and GERD (30.4 \pm 10.4 and $30.3 \pm 8.8$, respectively). Despite adequate serum levels, the authors emphasized the importance of constant monitoring of children with EoE, as they may be at additional risk for inadequate intake of calcium and vitamin $\mathrm{D}$, given the use of food allergen restriction diets ${ }^{(23)}$. Slack et al. (2015), in a study with children and adults diagnosed with EoE, evaluated the relationships between the $25(\mathrm{OH}) \mathrm{D}$ levels, demographic data and specific parameters of the disease. They noted that $25(\mathrm{OH}) \mathrm{D}$ levels in patients with EoE ranged from 9.63 to $83.9 \mathrm{ng} / \mathrm{mL}$ (median $28.9 \mathrm{ng} / \mathrm{mL}$ ) where, $52 \%$ of patients had vitamin D deficiency/ insufficiency ${ }^{(24)}$. It is noted that the average levels of vitamin D remained sufficient ${ }^{(23)}$ and insufficient ${ }^{(24)}$, respectively, in both studies cited; however, all the authors alert us to the need for a thorough investigation of these patients, as they have a restricted diet and a chronic inflammatory disease ${ }^{(23,24)}$.

Souto Filho et al. (2018), when conducting a study in order to investigate the association between $25(\mathrm{OH}) \mathrm{D}$ levels and absolute blood eosinophil count, the mean and median of $25(\mathrm{OH}) \mathrm{D}$ was $32.2 \pm 11.1 \mathrm{ng} / \mathrm{mL}$ and $30.9 \mathrm{ng} / \mathrm{mL}$ (minimum of 3.9 and maximum of $70.0 \mathrm{ng} / \mathrm{mL}$ ), respectively; and $46.5 \%$ of the individuals were $25(\mathrm{OH}) \mathrm{D}$ deficient/insufficient. Then they realized that $25(\mathrm{OH}) \mathrm{D}$ deficiency/insufficiency was associated with a higher blood eosinophil count $(P=0.001)$. They concluded that these results support the role of vitamin D in the immune response to eosinophils ${ }^{(25)}$.

Murdaca et al. (2019) when conducting a literature review to discuss the role of $25(\mathrm{OH}) \mathrm{D}$ in the pathogenesis of various autoimmune diseases and the validity of therapeutic supplementation, 
they found that several studies have shown that $25(\mathrm{OH}) \mathrm{D}$ can influence function of B cells, inhibiting their differentiation and proliferation, promoting their apoptosis and, ultimately, decreasing the production of immunoglobulins, including autoantibodies. Moreover, they also noted that $25(\mathrm{OH}) \mathrm{D}$ can also influence $\mathrm{T}$ cell function, reducing the proliferation and differentiation of $\mathrm{T}$ helper (Th) cells and promoting a change from a pro-inflammatory to a more tolerogenic immune status ${ }^{(26)}$. Armbruster-Lee et al. (2018) revealed that peripheral blood eosinophils in pediatric EoE patients have negative expression of VDR and negative expression of Transforming Growth Factor Beta (TGFB), indicating a profibrotic state, and that the negative regulation of VDR in eosinophils in patients with EoE may contribute to fibrosis in $\mathrm{EoE}^{(27)}$. These studies indicate the importance of monitoring $25(\mathrm{OH}) \mathrm{D}$ serum levels in EoE patients, since deficient/insufficient serum levels may cause an increased presence of eosinophils by the immune system and without a correct treatment to normalize $25(\mathrm{OH}) \mathrm{D}$ levels, esophageal fibrosis may occur.

EoE patients reported not consuming milk and dairy products, eggs and beef liver frequently, indicating a low consumption of vitamin $\mathrm{D}$ food sources. However, it is known that only $10 \%$ to $20 \%$ of vitamin D absorbed by humans comes from of the diet, the other $80 \%$ is synthesized endogenously, through exposure to UVB rays $^{(28)}$. This alerts us to pay more attention and provide correct guidance for exposure to the sun, at the right time, for sufficient time and with appropriate clothing to trigger a correct production of $25(\mathrm{OH}) \mathrm{D}$, as its inadequate/ deficient levels of $25(\mathrm{OH}) \mathrm{D}$ can influence the manifestation of the disease. In addition, health professionals should focus, from the moment of diagnosis, on monitoring and adhering to treatment, since correct adherence is essential to control the disease and prevent it from becoming a case of esophageal fibrosis ${ }^{(27)}$.

EoE patients reported daily sun exposure for longer periods than the control group. 20 minutes of sun exposure per day is recommended to trigger adequate vitamin $\mathrm{D}$ production. However, the amount of vitamin D produced from exposure to ultraviolet rays is proportional to the amount of skin exposed to the sun, where at least $25 \%$ of the surface area must be exposed body, and large areas such as arms and legs should be exposed directly to the $\operatorname{sun}^{(29,30)}$. The patients in this study reported that their exposure occurred during spring, summer and early autumn (data collection period), on the way to school or during school breaks, where they were always wearing shorts and a blouse; which corresponds to at least $25 \%$ of the bodily exposure. Although daily sun exposure was sufficient to trigger a correct production of vitamin D, EoE patients showed insufficient/deficient $25(\mathrm{OH}) \mathrm{D}$ levels. This result reinforces the possible that even in places with high levels of solar radiation, such as in southeastern Brazil, where the incidence of UVB rays remains high throughout the year, hypovitaminosis D may occur. Other influential factors may be skin color, time of exposure to the sun, use of sunscreen and pollution ${ }^{(29)}$. The present study analyzed only the skin color and found no association with the serum 25(OH)D levels. A study carried out by Peçanha et al. (2019) also found a prevalence $(57.3 \%)$ of $25(\mathrm{OH}) \mathrm{D}$ deficiency in children with recurrent wheezing and asthma. They found that most of their patients were declared non-white (brown, mulatto or black), but they also found no significant difference in $25(\mathrm{OH})$ $\mathrm{D}$ levels in relation to ethnicity. However, they found that vitamin D concentrations were inversely associated with wheezing events in the first year of life $(P=0.037)$, a personal history of atopic dermatitis and exposure to environmental pollution, and vitamin D supplementation in the first 2 years of life was associated as a protective factor for the studied population ${ }^{(31)}$. These results reaffirm the fact that $25(\mathrm{OH}) \mathrm{D}$ levels are associated with anti-inflammatory action of allergic/ inflammatory diseases; when serum $25(\mathrm{OH})$ levels were suboptimal, symptoms and the proliferation of diseases increased.

Most of the children and adolescents in the study were in the normal/ high BMI group. Only one malnourished patient was identified in the control group and two were identified in the case group. Of these two EoE patients, one was underweight for their age and the other very underweight, and both had inadequate $25(\mathrm{OH})$ D levels, which can be attributed to the restricted diet and the EoE itself; which can directly interfere with the nutritional status of the affected patients ${ }^{(32-34)}$.

Since the deficient/ insufficient levels of $25(\mathrm{OH}) \mathrm{D}$ directly influence the inflammatory state generated by the immune system ${ }^{(26)}$ and since EoE is a disease characterized by chronic esophageal inflammation ${ }^{(11)}$, the continuous monitoring of these patients should include $25(\mathrm{OH}) \mathrm{D}$ levels. This should include orienting patients to have correct exposure to the sun for a sufficient amount of time, with the use of appropriate clothing, to trigger the correct production of vitamin D.

The sample of the present study was of convenience, as EoE is a rare pathology. Patients were approached at the consultation and when they had a confirmed diagnosis. As it is a population of variable prevalence, it was not possible to calculate the power of the sample. Another limitation of this study was that the 24-hour recall was applied only to the EoE group, in addition it was not possible to reapply the 24 -hour recall in at least $30 \%$ of patients, due to the difficulty for patients to return to medical appointments, which prevented statistically adjusting the intrapersonal variability of intake. The variables analyzed in relation to sun exposure were also limited, as it was not analyzed whether the patient used sunscreen or not, and the level of pollution in the city studied was not measured. The sample size was limited, due to low compliance by most patients.

\section{CONCLUSION}

The present study demonstrated a higher frequency of insufficient/deficient levels of vitamin D in children and adolescents with EoE on a restricted diet. The $25(\mathrm{OH}) \mathrm{D}$ levels of these patients should be investigated and the correct exposure to the sun should be encouraged, while paying attention to the guidelines of the time of day, time spent in the sun and appropriate clothing to trigger the production of vitamin D. However, the sun exposure of the EoE group for more than 30 minutes in the sun did not seem to have provided a protective effect, even in a region with high levels of solar radiation. There was a significant difference only in the consumption of cow's milk between the case and control groups, showing us the low adherence to the restriction diet by the case group. No association was found between $25(\mathrm{OH}) \mathrm{D}$ levels and nutritional status. There was no association regarding the adequate or inadequate status of vitamin $\mathrm{D}$ and the consumption of vitamin $\mathrm{D}$ food sources. Multicenter studies with a larger number of cases should be performed to assess $25(\mathrm{OH}) \mathrm{D}$ levels and associated factors in pediatric patients with EoE. 


\section{ACKNOWLEDGEMENTS}

We would like to thank Dr. André Moreno Morcillo for his collaboration with the statistical analysis and the Resident in Immunology, Ana Laura Becker, for collaborating in the identification of the patients, and Dr. Matthew Ferreira for reviewing the translation of the article.

\section{Authors' contribution}

Teixeira TL: collected data, performed statistical analyses and elaborated the body of the article. Linden MA: collected data and elaborated the body of the article. Lomazi EA, Saron MGL, Riccetto AL, Bellomo-Brandão MA: elaborated the body of the article.

\section{Orcid}

Thaís Longo Teixeira: 0000-0002-1609-1248.

Marcela Almeida Linden Ferreira: 0000-0001-6136-8341.

Elizete Aparecida Lomazi: 0000-0001-5504-4746.

Margareth Galvão Lopes Saron: 0000-0001-5024-2188.

Adriana Lopes Riccetto: 0000-0002-1330-3591.

Maria Angela Bellomo-Brandão: 0000-0002-1145-2606.

Teixeira TL, Linden MA, Lomazi EA, Saron MGL, Riccetto AL, Bellomo-Brandão MA. Estudo caso-controle sobre o status da vitamina D em crianças e adolescentes com esofagite eosinofílica. Arq Gastroenterol. 2020;57(4):409-15.

RESUMO - Contexto - A vitamina D é um hormônio esteroide solúvel em gordura essencial e sua deficiência é um problema global de saúde pública, especialmente entre crianças e adolescentes. Fatores como baixa ingestão de fontes alimentares ricas em vitamina D, baixa absorção e menor exposição ao sol influenciam esse resultado. A vitamina D tem um efeito anti-inflamatório no organismo, promovendo a diferenciação regulatória das células T e recuperando a resposta das células T auxiliares 17 e a secreção de citocinas anti-inflamatórias. A esofagite eosinofílica (EoE) é uma doença crônica, caracterizada histologicamente por inflamação predominantemente eosinofílica. As abordagens terapêuticas mais comuns são as dietas eliminadoras de alérgenos, como a exclusão de leite de vaca, ovo, soja, trigo, amendoim e frutos do mar ou restrições alimentares mais específicas. Objetivo - Verificar os níveis séricos de vitamina $\mathrm{D}$ em crianças e adolescentes com EoE em dieta restrita e, analisar sua associação com estado nutricional, consumo de fonte alimentar, exposição ao sol e cor da pele. Métodos - Estudo caso-controle realizado na cidade de Campinas-SP, Brasil, no qual foram incluídos pacientes com idades entre 2 e 18 anos; aqueles com diagnóstico de EoE foram referidos como grupo de casos $(n=15)$; um grupo controle ( $n=17)$ também foi formado. Dados epidemiológicos, estado nutricional, dados sobre a ingestão de vitamina D (recordatório de 24 horas - realizado apenas por pacientes com EoE e ingestão autorreferida de fontes alimentares de vitamina D: leite e derivados, atum e sardinha enlatada, fígado de boi, ovos de galinha - aplicados em ambos os grupos) e o tempo diário de exposição ao sol ( $\geq 30 \mathrm{~min}$ ou $\leq 30 \mathrm{~min}$ ) foi registrado. As amostras foram coletadas para níveis séricos de 25 -hidroxi-vitamina $\mathrm{D}$, onde foram considerados níveis de suficiência $>30 \mathrm{ng} / \mathrm{mL}$, insuficiência 21 a $30 \mathrm{ng} / \mathrm{mL}$, deficiência $<20$ $\mathrm{ng} / \mathrm{mL}$. Resultados - Houve maior frequência de insuficiência / deficiência de vitamina $\mathrm{D}$ no grupo EoE $(P=0,035)$, mesmo com maior exposição ao sol $(P=0,035)$. A cor da pele não foi associada a níveis mais baixos de vitamina $\mathrm{D}$ nos dois grupos estudados. Não foi encontrada diferença no estado nutricional entre os grupos. Conclusão - O presente estudo demonstrou maior frequência de níveis inadequados / deficientes de vitamina D em crianças e adolescentes com EEo em dieta restrita. Quando necessário, os níveis séricos devem ser investigados e a exposição correta ao sol deve ser incentivada, com atenção especial às diretrizes recomendadas, tempo gasto ao sol e roupas adequadas para a absorção correta. Já a exposição por mais de 30 minutos ao sol não parece ter proporcionado um efeito protetor no grupo EoE, mesmo em uma região com altos níveis de radiação solar. Houve diferença significativa apenas no consumo de leite de vaca entre os grupos caso e controle, demonstrando a baixa adesão à dieta de restrição pelo grupo caso. Não foi encontrada associação entre os níveis séricos de hidroxivitamina D 25 e o estado nutricional. Além disso, não foi identificada associação quanto ao status adequado ou inadequado da 25 hidroxivitamina D e ao consumo de alimentos ricos em vitamina D. Estudos multicêntricos com número maior de casos devem ser realizados para avaliar os níveis séricos de hidroxivitamina D 25 e fatores associados em pacientes pediátricos com EEo.

DESCRITORES - Deficiência de vitamina D. Vitamina D. Esofagite eosinofílica. Crianças.

\section{REFERENCES}

1. Rosen CJ. Vitamin D insufficiency. N Engl J Med. 2011;364:248-54.

2. Filgueiras MS, Rocha NP, Novaes JF, Bressan J. Vitamin D status, oxidative stress, and inflammation in children and adolescents: A systematic review. Crit Rev Food Sci Nutr. 2020;60:660-9.

3. Ferreira CES, Maeda SS, Batista MC, Lazaretti-Castro M, Vasconcellos LS, Madeira M, et al. Posicionamento Oficial - Intervalos de referência da vitamina D - $25(\mathrm{OH})$ D. Soc Bras Patol Clínica/Medicina Lab e da Soc Bras Endocrinol e Metabol. 2018;25:1-8. Available from: http://www.sbpc.org.br/wp-content/ uploads/2017/12/PosicionamentoOficial_SBPCML_SBEM.pdf

4. Perezabad L, López-Abente J, Alonso-Lebrero E, Seoane E, Pion M, Correa-Rocha $\mathrm{R}$. The establishment of cow's milk protein allergy in infants is related with a deficit of regulatory T cells (Treg) and vitamin D. Pediatr Res. 2017;81:722-30.

5. Silva CM, Silva SA, Antunes MM, Silva GAP, Sarinho ESC, Brandt KG. Do infants with cow's milk protein allergy have inadequate levels of vitamin D? J Pediatr. 2017;93:632-8.
6. Dupont C, Chouraqui J, Linglart A, Bocquet A, Darmaun D, Feillet F, et al. Nutritional management of cow 's milk allergy in children: An update. Archives de Pediatrie. 2018;25:236-43.

7. Mahon BD, Wittke A, Weaver V, Cantorna MT. The targets of vitamin D depend on the differentiation and activation status of CD4 positive T cells. J Cell Biochem 2003;89:922-32.

8. Pichler J, Gerstmayr M, Szepfalusi Z, Urbanek R, Peterlik M, Willheim M. alpha, 25(OH)2D3 inhibits not onlyTh1 but also Th2 differentiation in human cord blood T cells. Pediatr Res. 2002;52:12-8.

9. Boonstra A, Barrat FJ, Crain C, Heath VL, Savelkoul HF, A O'Garra. 1 alpha, 25-Dihydroxyvitamin D3 has a direct effect on naive CD4(1) T cells to enhance the development of Th2 cells. J Immunol. 2001;167:4974-80.

10. Holick MF. The vitamin D deficiency pandemic: Approaches for diagnosis, treatment and prevention. Rev Endocr Metab Disord. 2017;18:153-65. 
11. Dellon ES. No Maintenance, No Gain in Long-term Treatment of Eosinophilic Esophagitis. Clin Gastroenterol Hepatol. 2019;17:397-99.

12. Sadovsky AI, Brandt GK, Duarte MA, et al. Practical guide for updating the scientific department of Gastroenterology: Eosinophilic Esophagitis. Brazilian Society of Pediatrics. 2018:1-15.

13. Hiremath G, Rogers E, Kennedy E, Hemler J, Acra S. Comparative Analysis of Eating Behavior of School - Aged Children with Eosinophilic Esophagitis and Their Caregivers' Quality of Life: Perspectives of Caregivers. Dysphagia. 2019;34:567-74.

14. Slack MA, Ogbogu PU, Phillips G, Platts-Mills TAE, Erwin EA. Serum vitamin $D$ levels in a cohort of adult and pediatric patients with eosinophilic esophagitis. Ann Allergy Asthma Immunol. 2015;115:45-50.

15. WHO. WHO Anthro for Personal Computers manual. WHO Anthro Softw Licens Agreem [Internet]. 2007; Available from: http://www.who.int/childgrowth/ software/en/.

16. Ghissassi FEl, Baan R, Straif K, Yann Grosse, Béatrice Secretan, Véronique Bouvard, et al. A review of human carcinogens--part D: radiation. Lancet Oncol. 2009;10:751-2.

17. Avanutri [internet]. Avanutri efficacy in nutrition, version 4.0, Available from: $<$ http://www.avanutri.com.br/>

18. Ross A, Manson EJ, Abrams AS, Aloia JF, Brannon PM, Clinton SK, et al. The 2011 report on dietary reference intakes for calcium and vitamina D from Institute of Medicine: What Clinicians need to kwow. J Clin Endocrinol Metab. 2011;96:53-8.

19. Holick MF. Evaluation, treatment, and prevention of vitamin D deficiency: An Endocrine Society clinical practice guideline. Metabolism, 2011;96:1911-30.

20. OpenEpi - Open Source Epidemiological Statistics for Public Health, version 3.01, Available from: https://www.openepi.com/Menu/OE_Menu.htm

21. IBM Corp. Released 2011. IBM SPSS Statistics for Windows, Version 15.0. Armonk, NY: IBM Corp.

22. Chan AW, Tetzlaff JM, Altman DG, Laupacis A, Gøtzsche PC, Krle A-Jerić K, et al. Statement: Defining standard protocol items for clinical trials. Ann Intern Med. 2013;158:200-7.
23. Mehta P, Furuta TG, Brennan T, Henry ML, Maune NC, Sundaram SS, et al. Nutritional state and feeding behaviors of children with eosinophilic esophagitis and gastroesophageal reflux disease. J Pediatr Gastroenterol Nutr. 2018;66:603-8.

24. Slack, M A, Ogbogu U P, Phillips G, Platts-Mills TAE, Erwin EA. Serum vitamin $\mathrm{D}$ levels in a cohort of adult and pediatric patients with eosinophilic esophagitis. Ann Allergy Asthma Immunol. 2015;115:45-50.

25. Souto FDTJ, Andrade SA, Ribeiro MF, Alves PAS, Simonini VRF. Impact of vitamin D deficiency on increased blood eosinophil counts. Hematol Oncol Stem Cell Ther. 2018;11:25-9.

26. Murdaca G, Tonacci A, Negrini S, Greco M, Borro M, Puppo F, Gangemi S. Emerging role of vitamin D in autoimmune diseases: An update on evidence and therapeutic implications. Autoimmun Rev. 2019;18:102350.

27. Armbruster-Lee, Cavender PC, Lieberman AJ. Understanding fibrosis in eosinophilic esophagitis: Are we there yet. J Leukoc Biol. 2018; 104:31-40.

28. Maeda SS, Borba VZ, Camargo MB, Silva DMW, Borges JLC, Bandeira F, et al. Recomendações da Sociedade Brasileira de Endocrinologia e Metabologia (SBEM) para o diagnóstico e tratamento da hipovitaminose D. Arq Bras Endocrinol Metabol.2014;58:411-33. doi 10.1590/0004-2730000003388.

29. Holick MF. Vitamin D: a D-Lightful health perspective. Nutr Rev. 2008;66(10 Suppl 2):S182-94.

30. Bouillon R, Okamura WH, Norman AW. Structure-function relationships in the vitamin D endocrine system. Endocr Rev. 1995;16:200-57.

31. Peçanha MB, Freitas BR, Moreira RT, Silva LS, Oliveira LL, Cardoso SA. Prevalence of vitamin D deficiency and its relationship with factors associated with recurrent wheezing. J Bras Pneumol. 2019;45:e20170431.

32. Lucendo AJ, Molina-Infante J, Arias A, von Arnim U, Bredenoord AJ, Bussmann C, et al. Guidelines on eosinophilic esophagitis: evidence-based statements and recommendations for diagnosis and management in children and adults. United European Gastroenterol J. 2017;5:335-58.

33. Franciosi JP, Tam V, Liacouras CA, Spergel JM. A case-control study of sociodemographic and geographic characteristics of 335 children with eosinophilic esophagitis. Clin Gastroenterol Hepatol. 2009;7:15-9.

34. Dellon ES, Liacouras AC, Molina-Infante J, Furuta GT, Spergel JM, Zevit N, et al. Updated international consensus diagnostic criteria for eosinophilic esophagitis: proceedings of the AGREE conference. Gastroenterology. 2018;155:1022-33. 